\title{
PENINGKATAN MOTIVASI DAN HASIL BELAJAR PADA MATA PELAJARAN PEMOGRAMAN DASAR MENGGUNAKAN MODUL DI SMKN 2 SUMBAWA
}

\author{
Lies Pebruanti \\ SMKN 2 Sumbawa \\ liespebruanti@gmail.com \\ Sudji Munadi \\ Universitas Negeri Yogyakarta \\ sudji.munadi@uny.ac.id
}

\begin{abstract}
Abstrak
Penelitian ini bertujuan: (1) untuk meningkatkan motivasi belajar siswa, dan (2) untuk meningkatkan hasil belajar siswa agar tercapainya ketuntasan klasikal pada mata pelajaran pemograman dasar siswa kelas Xjurusan Multimedia di SMKN 2 Sumbawa. Penelitian ini merupakan penelitian tindakan kelas yang menggunakan model Kemmis dan Mc. Taggart (Perencanaan, pelaksanaan, observasi, dan refleksi). Subjek dalam penelitian ini adalah siswa kelas X Multimedia SMKN 2 Sumbawa, NTB yang berjumlah 34 orang melibatkan guru dan seorang observer. Data motivasi dan nilai sikap diambil menggunakan angket. Data keterlaksanaan proses pembelajaran diambil dengan menggunakan lembar observasi. Data nilai pengetahuan dan unjuk kerja diambil menggunakan skala penilaian yang dilengkapi dengan rubrik. Teknik analisis data motivasi dan nilai sikap menggunakan analisis deskriptif kemudian digolongkan kedalam skor baku untuk mengkategorisasikan motivasi belajar dan nilai sikap. Hasil penelitian ini menunjukkan bahwa: (1) pengunaan modul pembelajaran dapat meningkatkan motivasi belajar siswa. (2) penggunaan modul dapat meningkatkan hasil belajar (nilai sikap, nilai pengetahuan dan praktik).
\end{abstract}

Kata kunci: penelitian tindakan kelas, motivasi belajar, hasil belajar, modul

\section{IMPROVING MOTIVATION AND LEARNING OUTCOMES IN BASIC PROGRAMMING USING MODULES IN SMKN 2 SUMBAWA}

\begin{abstract}
This research aims to: (1) improve student's motivation and (2) improve student's learning outcomes to achieve the classical completeness on basic programming course in class X Multimedia majors at SMKN 2 Sumbawa. This research is a classroom action research that uses Kemmis and Mc. Taggart (planning, implementation, observation, and reflection) models. Subjects in this study is the tenthgrade of Multimedia students at SMKN 2 Sumbawa NTB amounting to 34 people involving teachers and an observer. The motivation data and value of attitude were taken using a questionnaire and the data of learning process was taken using observation sheets. The knowledge and performance values were taken using a assessment scale which was equipped with a rubric. The data analysis technique of motivation and value of attitude used descriptive analysis and were classified into raw scores to categorize the value of learning motivation and attitudes. The result of this research are as follows: (1) Using learning module can improve student's motivation. (2) Using learning module to improve learning outcomes (attitudes, knowledge and practices).
\end{abstract}

Keywords: classroom action research, motivation, learning outcomes, modules 


\section{PENDAHULUAN}

Pemerintah melalui Undang-Undang Nomor 20 Tahun 2003 tentang Sistem Pendidikan Nasional menjelaskan bahwa pendidikan kejuruan merupakan pendidikan yang mempersiapkan peserta didik untuk bekerja dalam bidang tertentu. Batasan pendidikan kejuruan tersebut menunjukkan bahwa pendidikan kejuruan identik dengan pendidikan dunia kerja. UNESCO Paris (2004, p.19) menyebutkan Sekolah Kejuruan bertujuan untuk: (1) to broaden educational horizons by serving as an introduction to the world of work, and the world of technology; (2) to orient those with the interest and ability in technical and vocational education; (3) to promote in those who will leave formal education with no specific occupational aims or skills, attitudes and thought processes. (1) memperluas cakrawala pendidikan dengan melayani sebagai pengantar dunia kerja, dan dunia teknologi; (2) untuk mengarahkan orangorang dengan minat dan kemampuan di bidang pendidikan teknis dan kejuruan; dan (3) menjadi sarana bagi mereka yang akan meninggalkan pendidikan formal dimana bukan hanya keterampilan, tapi sikap dan proses berpikir dalam bekerja. Pendidikan kejuruan merupakan yang berorientasi memberikan kualifikasi khusus untuk mengakses pasar tenaga kerja. Pasar tenaga kerja terus maju dan berkembang, sehingga menimbulkan kesenjangan antara pekerja dengan lapangan kerja yang semakin jauh. Oleh sebab itu, dibutuhkan tahapan sebagai usaha untuk meraih tujuan pendidikan kejuruan.

Langkahuntukmencapaitujuan pendidikan kejuruan yang dilakukan oleh pemerintah adalah mengembangkan pendidikan kejuruan yang bersifat formal. Melalui Peraturan Pemerintah Tahun 2008 Nomor 74 Pasal 1 Ayat 21 bahwa Sekolah Menengah Kejuruan (SMK) adalah salah satu bentuk pendidikan formal yang menyelenggarakan pendidikan kejuruan pada jenjang Pendidikan Menengah sebagai lanjutan dari SMP, MTs, atau bentuk lain yang sederajat atau lanjutan dari hasil belajar yang diakui sama atau setara SMP atau MTs. SMK merupakan pendidikan formal pada jenjang menengah yang mempersiapkan dan mengembangkan kompetensi siswa untuk memasuki dunia kerja. Oleh sebab itu, dibutuhkan kualifikasi lulusan SMK yang sesuai dengan kebutuhan dunia kerja.

Lulusan dari SMK diharapkan dapat menjadi tenaga kerja yang handal yang mampu bekerja pada tingkat menengah dan memiliki sikap kemandirian, serta memiliki kesiapan baik mental maupun fisik untuk menghadapi persaingan kerja. SMK diharapkan mampu menjadi tempat yang dapat mengembangkan, menyediakan dan melatih sumber daya manusia siap pakai dan dibutuhkan dunia kerja secara nyata. Oleh karena itu, keberhasilan pendidikan di SMK harus ditunjang dengan dukungan pemerintah serta proses belajarmengajar didalamnya.

Keberhasilan sebuah Sekolah Menengah Kejuruan tidak terlepas dari proses belajar mengajar di dalamnya, baik pelajaran teori maupun pelajaran praktik. Pelajaran praktik merupakan salah satu faktor pendukung ketercapaian proses keberhasilan belajar dan mengajar di sekolah kejuruan. Mata pelajaran praktik selain harus dapat memahami konsep dasar juga harus mengetahui teori-teori penunjang dalam proses belajar mengajar.

Permasalahan yang dihadapi dalam pembelajaran selama proses belajar mengajar pada mata pelajaran pemrograman dasar. Salah satu permasalahan yang dihadapi adalah keterbatasan sumber materi yang diterima oleh siswa. Sumber materi yang diterima saat ini masih terbatas pada apa yang disampaikan oleh guru tanpa adanya media belajar lain sebagai sumber materi. Kelemahan materi yang disampaikan tanpa bantuan sebuah media pembelajaran adalah: (1) guru sulit untuk menjelaskan materi pembelajaran tertentu dengan papan tulis; (2) kemampuan guru masih terbatas dalam mentrasfer materi ajar, sehingga siswa sulit dalam menerima dan mencerna apa yang dijelaskan oleh guru; (3) teknik dan metode mengajar yang digunakan kaku dan tidak bervariasi yang menyebabkan gairah belajar hilang (Mustamin, 2005).

Proses belajar mengajar pada mata pelajaran pemograman dasar dalam mengaplikasikan teori dilakukan praktik dengan menggunakan bahasa $\mathrm{C}++$. Bahasa $\mathrm{C}++$ diterapkan menggunakan program code 
blocks yang bersifat case sensitive, sehingga menuntut siswa untuk lebih teliti dan fokus dalam penulisan kode program. Materi tipe data sangat penting dalam penulisan sebuah kode program karena menentukan pengolahan input dan output dari program. Penilaian hasil belajar pada mata pelajaran pemograman dasar selama ini masih terfokus pada produk (hasil akhir) bukan pada proses. Penilaian yang hanya berdasarkan produk tidak dapat mengoptimalkan penilaian, sehingga memicu siswa mengerjakan soal praktik dengan cara try and error tanpa memperdulikan alur program. Hal tersebut mengakibatkan kurang minatnya siswa untuk belajar pemograman dasar yang berimbas kepada prestasi belajar yang tidak meningkat.

Ada dua jenis utama dari programmer pemula yang ditandai dengan saat bertemu dengan masalahyang dilakukanyaitu "berhenti" dan "penggerak". Ketika dihadapkan dengan masalah programmer akan berhenti bekerja dan mencari bantuan, sedangkan penggerak akan terus berusaha untuk memecahkan masalah dengan umpan balik dari kode program baik secara aktif atau tidak aktif. Hal tersebut dipengaruhi oleh penguasaan materi dasar dan motivasi belajar. Penguasaan materi dasar secara mendalam dapat mengurangi kesalahan yang berakibat errornya sebuah program, sedangkan motivasi belajar dapat membantu siswa untuk menjadi "penggerak" sebagai programmer pemula. Mc. Donald menyatakan "motivation is an energy change within the person characterized by effective arousal and anticipatory goal reaction" (Sardiman, 2011, p.73). Motivasi merupakan perubahan energi yang terjadi dalam diri seseorang yang ditandai dengan munculnya efektif dan reaksi untuk mencapai tujuan. Seorang programmer pemula membutuhkan motivasi belajar dalam menyelesaikan permasalahan melalui program. Faktor kunci bagi kesuksesan pembelajaran adalah motivasi belajar (Reid, 2009, p.19). Oleh sebab itu, untuk meningkatkan prestasi belajar siswa harus dimulai dari peningkatan motivasi belajar.

Berdasarkan hasil survai awal yang dilakukan pada siswa kelas X di SMK Negeri 2 Sumbawa program studi Multimedia dengan jumlah siswa 34 orang. Hasil survai ditinjau dari sarana yang ada di dalam laboratorium $11,43 \%$ komputer yang ada tidak dapat dioprasikan. Keterbatasan tersebut membuka peluang pada siswa melakukan kegiatan selain belajar.

Hasil ulangan Akhir Semester Genap (UAS) kelas X tahun pelajaran 2011/2012 dengan jumlah siswa sebanyak 24 orang pada mata pelajaran pemograman dasar tergolong masih rendah. Daya serap siswa cukup tinggi mencapai $82,71 \%$, akan tetapi ketuntasan klasikal yang dicapai hanya $41,67 \%$. keberhasilan suatu pembelajaran dikatakan tuntas, jika jumlah siswa yang telah mencapai nilai KKM sebanyak minimal $85 \%$ dari total siswa (Trianto, 2012, p.241). Maka dari itu, salah satu cara alternatif yang dapat digunakan sebagai usaha meningkatkan hasil belajar adalah dengan meningkatkan pemahanam dan penguasaan materi pada diri siswa untuk melakukan praktik. Keterbatasan waktu dalam melakukan praktikum, sehingga kurang interaksi dalam proses belajar mengajar antara guru dengan siswa. Akibat dari kurangnnya interaksi dalam proses belajar mengajar menyebabkan tingkat pemahaman siswa terhadap materi yang disampikan oleh guru tidak maksimal. Oleh sebab itu, diperlukan suatu media pembelajaran yang mampu menyajikan materi tanpa batasan tertentu.

Penerapan media pembelajaran sebagai sumber belajar diharapkan dapat meningkatkan pemahaman siswa yang diiringi peningkatan prestasi belajar. Sejalan dengan penelitian yang dilakukan oleh Yunita Shintania (2010), Agus Kamaludin (2011), dan Iqma Novianti (2010) yang menyatakan bahwa hasil belajar siswa yang menggunakan media pembelajaran modul dinyatakan efektif untuk diterapkan dalam proses pembelajaran berdasarkan penilaian unjuk kerja siswa yang menunjukkan ketuntasan. Oleh sebab itu, ketersediaan modul pelajaran pemograman sangat dibutuhkan baik media pembelajaran berupa software atau media pembelajaran cetak sebagai sumber materi.

"A medium is something we use when we want to communicate with people indirectly, rather than in person or by face-to-face contact" (Buckingham, 2012, p. 3). Media 
adalah sesuatu yang digunakan ketika ingin berkomunikasi dengan orang-orang secara tidak langsung, daripada secara langsung atau melalui kontak tatap muka. Pembelajaran dengan berbantuan media pembelajaran dapat memberikan keleluasaan pada siswa untuk belajar sendiri sesuai dengan kemampuan dan gaya belajar masing-masing. Media pembelajaran dapat meningkatkan ketertarikan dan interaksi, meningkatkan efisiensi dan kualitas hasil belajar, menumbuhkan sikap positif siswa, mengubah peran guru, mengkongkritkan materi yang abstrak, membantu mengatasi keterbatasan panca indra, dan meningkatkan daya retensi siswa (Supriatiningrum, 2013, p.321). Selain itu, dengan media pembelajaran dapat membantu meningkatkan pemahaman, menyajikan data dengan menarik dan terpercaya, memudahkan penafsiran data, memadatkan informasi, serta membangkitkan motivasi dan minat siswa dalam belajar (Kustandi \& Sutjipto, 2013 , p. 19). Penerapan media pembelajaran sangat dibutuhkan karena berperan dalam meningkatkan motivasi belajar siswa.

Penerapan alat bantu pembelajaran berupa modul karena mengingat kemampuan daya serap dan cara belajar siswa yang berbedabeda. "Each learner has his or her own learning style". Bahwa setiap siswa memiliki gaya belajar sendiri (Alias, 2012, p.84). Keleluasaan yang diberikan kepada siswa untuk melakukan pembelajaran dengan gayanya sendiri dapat meningkatkan kenyamanan belajar yang mengakibatkan meningkatnya motivasi belajar. "It has been observed that when instruction is aligned with the learner's learning styles learning achievements will increase together with affective and motivational advantages ". Ketika instruksi sejalan dengan gaya belajar siswa maka akan meningkatkan prestasi belajar dan bersama dengan dengan keefektifan dan meningkatkan motivasi (Aviles \& Moreno dalam Alias, 2014, p. 30). Modul merupakan satuan program belajar mengajar yang terkecil, yang dipelajari oleh siswa sendiri secara perorangan atau diajarkan oleh siswa kepada dirinya sendiri (Winkel, 2009, p.472). Belajar sendiri dapat meningkatkan rasa tanggung jawab siswa terhadap apa yang telah dilakukan.
Karakteristik siswa dilihat dari segi perekonomian cukup heterogen dimana tidak semua siswa memiliki komputer PC/Laptop di rumah, sehingga diharapkan dengan penerapan modul siswa dapat mengulang materi tersebut berkali-kali agar mampu memahami materi pembelajaran tersebut. Penggunaan media pembelajaran modul berdiri sendiri yang artinya tidak tergantung pada perangkat lain. Proses belajar memerlukan komputer sebagai pengaplikasian dari isi modul, tanpa mengurangi keefektifan modul dalam meningkatkan pemahaman siswa dalam belajar. Di dalam modul telah terdapat materi sehingga siswa tidak perlu mencatat materi yang disampaikan oleh guru, siswa hanya perlu memperhatikan dan memahami penjelasan dari guru. Berkurangnya kegiatan mencatat dapat menghemat waktu dalam penyampaian materi dan memoptimalkan waktu pada saat melakukan praktikum. Media pembelajaran modul ini juga sangat fleksibel artinya dapat digunakan kapan saja dan dimana saja tidak dibatasi ruang dan waktu (Hogan \& Garling, 2008, p.5).

Proses belajar mengajar dengan bantuan media pembelajaran modul ini, diharapkan dapat meningkatkan pemahaman belajar praktik siswa yang akan diikuti dengan meningkatnya hasil belajar. Keberhasilan proses belajar mengajar dapat diukur dari keberhasilan siswa yang mengikuti kegiatan pembelajaran tersebut. Peningkatan prestasi belajar dapat dilihat dari tingkat pemahaman dan penguasaan materi untuk melakukan praktik yang diukur melalui hasil belajar. Semakin tinggi tingkat pemahaman dan penguasaan materi dalam melakukan praktik, maka semakin tinggi tingkat keberhasilan pembelajaran.

Keberhasilan pembelajaran dalam Kurikulum 2013 diukur dari tiga aspek. Aspek penilaian pembelajaran pada kurikulum 2013, yaitu: aspek sikap, aspek pengetahuan, dan aspek psikomotor. Pelaksanaan Kurikulum 2013 menerapkan pendekatan saintifik atau scientific approach yang sering dikenal dengan pendekatan ilmiah. Langkah pembelajaran dengan menggunakan pendekatan saintifik disesuaikan dengan standar kelulusan, yakni pengembangan aspek sikap, aspek 
pengetahuan, dan aspek psikomotor yang dilakukan dalam pengetahuan. Aspek sikap diperoleh dari aktivitas menerima, menjalankan, menghargai, menghayati, dan mengamalkan. Aspek pengetahuan diperoleh dari aktivitas mengingat, memahami, menerapkan, menganalisis, mengevaluasi, dan mencipta. Aspek keterampilan diperoleh dari aktivitas mengamati, menanya, mencoba, menalar, menyaji, dan mencipta. Ketiga aspek pembelajaran tersebut diterapkan secara langsung dan saling berkaitan satu sama lain. Ketiga aspek tersebut diyakini sebagai inti pokok pembelajaran saintifik yang diberikan dengan porsi seimbang dari ketiganya. Keseimbangan antara kemampuan untuk menjadi manusia (soft skill) dengan kecakapan dan kemampuan untuk menjadi manusia (hard skill) sebagai hasil akhir dari pembelajaran.

Proses pembelajaran dilakukan dengan model Kemmis dan Mc. Taggart untuk melihat seberapa besar peningkatan hasil belajar yang dicapai siswa dengan penerapan sebuah media pembelajaran. Tindakan tersebut dilakukan dengan melihat fenomena-fenomena yang terjadi di dalam kelas saat proses pembelajaran berlangsung pada kondisi yang sebenarnya. Penelitian ini merupakan penelitian tindakan kelas (classroom action research). Action research is simply a form of self-reflective enquiry undertaken by participants in social situations in order to improve the rationality and justice of their own practices, their understanding of these practices, and the situations in which the practices are carried out (Carr \& Kemmis, 1986, p.162). Penelitian tindakan kelas didefinisikan sebagai suatu kajian yang bersifat reflektif untuk memantapkan alasan dan ketepatan dari pelaku penelitian, pemahaman terhadap praktik tersebut, situasi pada saat praktik dilakukan. Penelitian tindakan umumnya dilakukan oleh guru pada kelas sendiri karena adanya permasalahan yang spesifik dalam proses belajar mengajar atau ingin meningkatkan hasil belajar yang dilaksanakan dalam situasi yang sebenarnya. penelitian tindakan kelas menggunakan model Kemmis dan Mc. Taggart yang dilakukan dalam 4 tahap, yaitu: (1) perencanaan (planning); (2) tindakan (action); (3) observasi (observing); dan (4) refleksi (reflecting). Tahap Perencanaan dilakukan oleh peneliti dan guru sebagai kolabolator berdasarkan hasil refleksi pada siklus pertaman, tahap pelaksanaan berdasarkan rencana yang telah disusun pada tahap perencanaan, tahap observasi dilakukan oleh dua orang yaitu: peneliti dan obsever yang menjabat sebagai ketua program studi multimedia, tahap refleksi melakukan analisis data yang diperoleh untuk mengetahui hasil yang dicapai. Hasil refleksi tersebut dipergunakan untuk memperbaiki tindakan pada siklus berikutnya.

\section{METODE PENELITIAN}

\section{Jenis penelitian}

Penelitian ini merupakan penelitian tindakan kelas (classroom action research). Jenis penelitian tindakan kelas menggunakan model Kemmis dan Mc. Taggart yang dilakukan dalam 4 tahap, yaitu: (1) perencanaan (planning); (2) tindakan (action); (3) observasi (observing); dan (4) refleksi (reflecting). Penerapan model dilakuan dengan menggabungkan tahap tindakan dan observasi secara bersamaan yang dilaksanakan pada tahap tindakan (Pardjono, 2007, p.22)

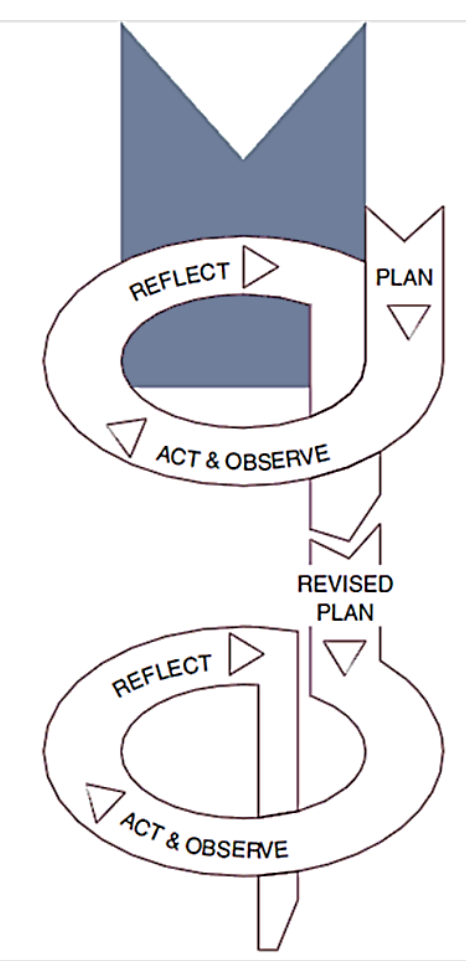

Gambar 1. Desain Penelitian Tindakan Kelas Model Kemmis \& Mc. Taggart. 


\section{Waktu dan Tempat Penelitian}

Penelitian dilakukan pada semester 2 (genap) tahun pelajaran 2014/2015 dari bulan Januari sampai dengan bulan Februari 2015. Penelitian dilaksanakan di SMK Negeri 2 Sumbawa, Nusa Tenggara Barat.

\section{Subjek Penelitian}

Subjek penelitian ini adalah siswa Kelas X program studi Multimedia di SMK Negeri 2 Sumbawa Besar Tahun Pelajaran 2014/2015 yang berjumlah 34 siswa dalam satu kelas pembelajaran.

\section{Skenario Tindakan}

Tindakan yang dilakukan dalam penelitian ini adalah penerapan media pembelajaran modul untuk meningkatkan motivasi dan hasil belajar siswa. Siklus pertama pada tahap perencanaan menyusun kegiatan dengan cermat dan tepat agar mampu mengatasi permasalahan yang ada. Perencanaan PTK merupakan langkah pemilihan media pembelajaran yang disesuaikan dengan kondisi siswa. Sehubungan dengan peneliti bukan sebagai guru, maka pengamatan selama proses penelitian dilakukan oleh peneliti dan observer yang menjabat sebagai kepala program studi Multimedia.

Tahap perencanaan dilakukan berdasarkan permasalahan yang telah ditemui dilapangan. Adapun tahap perencanaan yang dilakukan adalah: Rincian kegiatan pembelajaran pada siklus pertama, yaitu dengan melaksanankan pembelajaran dengan media modul yang dikemas sesuai dengan RPP, sebagai berikut: 1) mempersiapkan jadwal pelaksanaan tindakan, 2) mempersiapkan rencana pekasanaan pembelajaran (RPP) yang menerapakan media pembelajaran berupa modul, 3) mempersiapkan peralatan yang digunakan dalam melakukan praktik sebagai implementasi dari kognitif, dan 4) mempersiapkan instrumen penelitian yang terdiri atas lembar angket motivasi, lembar observasi keterlaksanaan pembelajaran, lebar penilaian antar teman, dan instrumen hasil belajar pada aspek kognitif dan psikomotor.

Tahap pelaksanaan dilakukan berdasarkan RPP yang telah dipersiapkan pada tahap perencanaan. Pelaksanaan pembelajaran dibagi menjadi 3 kegiatan, yaitu: kegiatan pendahuluan, kegiantan inti, dan kegiatan penutup.

Tahap pengamatan dilakukan oleh peneliti dan seorang observer untuk melakukan pengamatan terhadap pelaksanaan pembelajaran menggunakan media pembelajaran berupa modul. Pengamatan dilakukan bertujuan untuk mengetahui apakah proses pelaksanaan pembelajaran telah sesuai dengan rencana yang telah disusun atau belum dan mengisi lembar observasi keterlaksanaan pembelajaran.

Tahap refleksi merupakan tindakan yang dilakukan peneliti bersama guru sebagai kolaborator. Peneliti dan guru melaksanakan penilaian untuk mengetahui sejauh mana peningkatan yang dicapai siswa terhadap aspek motivasi dan hasil belajar. Berdasarkan hasil refleksi tersebut, dipergunakan untuk mengetahui sejauh mana tindakan yang dilakukan berpengaruh terhadap variabel yang diamati. Hasil refkelsi kemudian dijadikan sebagai acuan untuk merencanakan tindakan pada siklus kedua.

Siklus kedua dilakukan langkah-langkah yang sama dengan siklus pertama karena seluruh kegiatan yang dilakukan pada siklus selanjutnya merupakan hasil dari refleksi siklus sebelumnya.

\section{Data, Intrumen, dan Teknik Pengumpulan Data}

Pengumpulan data dalam penelitian ini dilakukan dengan 3 (dua) macam, yaitu: angket motivasi belajar siswa pada mata pelajaran pemrograman dasar, lembar observasi keterlaksanaan pembelajaran, lembar penilaian antar teman, dan tes hasil belajar siswa. Angket motivasi diberikan kepada siswa untuk mendapatkan data mengenai peningkatan motivasi belajar, terhadap pelaksanaan pembelajaran pemrograman dasar dengan menggunakan media modul. Lembar observasi keterlaksanaan kegiatan tindakan kelas diisi oleh peneliti dan observer, yang membantu dalam menangkap fenomena-fenomena yang terjadi di dalam kelas pada saat proses belajar mengajar. Sedangkan hasil belajar dilakukan dengan angket penilaian antar teman, soal pilihan ganda dan soal praktikum. Pelajaran 
pemrograman dasar pada kelas $\mathrm{X}$ semester dua merupakan pelajaran penerapan, sehingga pengumpulan data dilakukan di laboratorium. Teknik pengumpulan data pada hasil belajar (pengetahuan dan praktikum) menggunakan form penilaian dengan indikator penilaian, yaitu: pengetahuan, proses, hasil, dan penilaian waktu.

Lembar angket yang digunakan dalam penelitian ini untuk mendapatkan informasi mengenai motivasi belajar siswa, terhadap penerapan media pembelajaran modul. Penggunaan angket motivasi belajar bertujuan untuk mengetahui seberapa peningkatan motivasi belajar siswa dengan penerapan media pembelajaran modul tersebut. Meningkatnya motivasi belajar siswa diasumsikan dapat mempengaruhi peningkatan hasil belajar. Lembar angket motivasi belajar siswa disusun dengan menggunakan skala Likert dengan 5 (lima) pilihan, yaitu: Sangat Setuju (SS), Setuju (S), Ragu-ragu (R), Tidak Setuju (TS), dan Sangat Tidak Setuju (STS). Penskoran Pernyataan angket motivasi terdiri dari peryataan yang bersifat positif dan negatif. Terdapat perbedaan penilaian dari kedua pernyataan tersebut. Untuk pernyataan positif diberi skor 4 untuk kategori Sangat Setuju, skor 3 untuk kategori Setuju, skor 3 untuk kategori Ragu-ragu, skor 2 untuk kategori Tidak setuju, dan skor 1 untuk kategori Sangat Tidak Setuju. Penskoran untuk pernyataan negatif dari $1-4$.

Angket yang digunakan dalam pengumpulan data tentang motivasi belajar siswa menggunakan angket model ARCS yang dikembangkan oleh Keller. Angket motivasi belajar model ARCS terdiri dari 4 (empat) indikator, yaitu: perhatian, relevansi, kepercayaan diri, dan kepuasan.

Pengukuran kognitif dilakukan dengan pemberian soal pilihan ganda dan untuk mengukur kemampuan psikomotor dilakukan dengan praktik yang penilaiannya menggunakan skala penilaian (rating scale) yang dilengkapi dengan rubrik.

Penilaian sikap menggunakan penilaian antar teman. Pernyataan angket penilaian sikap antar teman terdiri dari peryataan yang bersifat positif dan negatif. Penilaian untuk pertanyaan positif diberi skor 4 - 1, sedangkan untuk pernyataan negatif diberi skor sebaliknya yaitu $1-4$.

\section{Teknik Analisis Data}

Data analisis motivasi belajar didapatkan dengan instrument berbentuk checklist dalam skala Likert, dengan leluasa kemudian dianalisa untuk dirubah menjadi data kuantitatif, data tersebut dianalisis menggunakan analisis statistik deskriptif. Analisis statistik deskriptif dilakukan untuk memperoleh skor tentang motivasi belajar. Data tersebut selanjutnya digolongkan kedalam skor baku.

Data analisis penilaian sikap (afektif) didapatkan dengan instrument berbentuk checklist dalam skala Likert, kemudian dianalisa untuk dirubah menjadi data kuantitatif, data tersebut dianalisis menggunakan analisis statistik deskriptif. Analisis statistik deskriptif dilakukan untuk memperoleh skor tentang penilaian sikap. Data tersebut selanjutnya digolongkan kedalam skor baku.

Penyekoran angket penilaian sikap antar teman dilakukan dengan rentang 1 sampai 4 . Perhitungan analisis data berdasarkan pada skor rata-rata indikator pernyataan. Menentukan kriteria keberhasilan hasil penilaian sikap menggunakan klasifikasi konversi skor penilaian.

Tabel 1. Kategori Penilaian Sikap

\begin{tabular}{cc}
\hline Interval skor & Kategori \\
\hline $3,66-4,00$ & Sangat baik \\
$2,66-3,65$ & Baik \\
$1,66-2,65$ & Cukup \\
$1,00-1,65$ & Kurang \\
\hline
\end{tabular}

Sumber: Permendikbud Nomor 81A Tahun 2013

\section{HASIL PENELITIAN DAN PEMBAHASAN}

\section{Siklus Pertama}

Ketercapaian ketuntasan siswa mencapai 23 orang dengan persentase sebesar $67,65 \%$ dan 11 orang belum tuntas dengan persentase sebesar 32,35\%. Standar deviasi (SD) sebesar 0,70 penyimpangan data nilai yang diperoleh siswa memiliki variabilitas tinggi. Persentase 
ketercapaian dari tiap pernyataan, sebgai berikut:

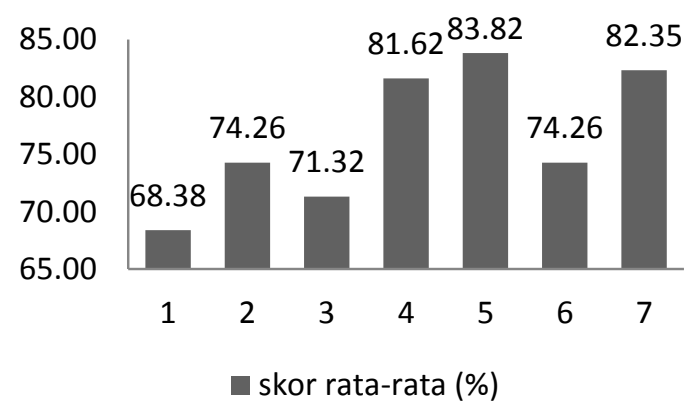

Gambar 2. Persentase Skor Rata-Rata

Keterangan

1. Mendengarkan penjelasan dari guru

2. Memakai seragam sesuai tata tertib

3. Mengerjakan tugas yang diberikan oleh guru

4. Membuat kegaduhan/keributan di dalam kelas

5. Mengganggu teman saat belajar

6. Melakukan kegiatan lain pada saat guru menjelaskan

7. Terlambat memasuki ruang belajar

Berdasarkan gambar grafik di atas, menunjukkan bahwa persentase siswa yang mendengarkan penjelasan dari guru sebesar $68,38 \%$, siswa yang menggunakan seragam bengkel pada saat pelajaran praktik sebesar $74,26 \%$, siswa yang telah mengerjakan tugas yang diberikan oleh guru sebesar $71,32 \%$. Persentase siswa yang melakukan tindakan negatif pada saat proses pembelajaran berlangsung seperti membuat kegaduhan/ keributan di dalam kelas sebesar $81,62 \%$, menganggu teman saat belajar sebesar $83,82 \%$, melakukan kegiatan lain pada saat guru menjelaskan sebesar $74,26 \%$, dan siswa yang terlambat memasuki laboratorium sebesar $82,35 \%$. Jumlah siswa yang melakukan kegiatan lain di kelas masih cukup tinggi.

Berdasarkan hasil analisis statistik deskriptif terhadap skor rata-rata yang diperoleh siswa, dapat dideskripsikan nilai sikap berdasarkan penilaian antar teman pada siklus pertama dengan mengkategori frekuensi siswa sebagai berikut:
Tabel 2. Frekuensi Nilai Afektif

\begin{tabular}{ccc}
\hline Kategori & Frekuensi & Persentase \\
\hline Sangat Baik & 2 & $5,88 \%$ \\
Baik & 25 & $73,53 \%$ \\
Cukup & 7 & $20,59 \%$ \\
Kurang & 0 & $0,00 \%$ \\
\hline
\end{tabular}

Berdasarkan hasil analisis data di atas, jumlah siswa yang lulus sebanyak 27 siswa. Siswa yang telah lulus masuk kedalam kategori Sangat baik sebanyak 2 siswa dengan persentase sebesar 5,88\% dan kategori Baik sebanyak 25 siswa dengan persentase $73,53 \%$. Siswa yang belum lulus sebanyak 7 siswa yang terdapat pada kategori Cukup dengan persentase sebesar $20,59 \%$ dan kategori Kurang sebanyak 0 siswa. Jadi siswa yang lulus sebesar $79,41 \%$

Hasil motivasi belajar siswa dikategorikan, sebagai berikut:

Tabel 3. Frekuensi Motivasi Belajar

\begin{tabular}{ccc}
\hline Kategori & Frekuensi & Persentase \\
\hline Sangat baik & 0 & $0 \%$ \\
Baik & 27 & $79,41 \%$ \\
Cukup & 7 & $20,59 \%$ \\
Kurang & 0 & $0 \%$ \\
\hline
\end{tabular}

Berdasarkan Tabel di atas, jumlah siswa masuk pada kategori Baik sebanyak 27 orang dengan persentase $79,41 \%$ dan kategori Cukup sebanyak 7 orang sengan persentase $20,59 \%$. Dengan demikian, masih terdapat beberapa siswa yang masih kurang memperhatikan materi pelajaran dan masih bingung dengan materi yang disampaikan oleh guru, sehingga mempengaruhi kepercayaan diri siswa. Jumlah siswa yang pasif ketika mengikuti pembelajaran jumlahnya masih banyak. Kepasifan siswa mengikuti pelajaran terutama terlihat ketika guru memberikan kesempatan untuk bertanya materi yang belum difahami dan mencoba menjawab pertanyaan yang diberikan guru.

\section{Siklus Kedua}

Ketercapaian ketuntasan siswa mencapai 26 orang dengan persentase sebesar $76,47 \%$ dan 8 orang belum tuntas dengan persentase $23,53 \%$. Standar deviasi (SD) sebesar 0,48 
penyimpangan data nilai yang diperoleh siswa variabilitas mulai menurun.

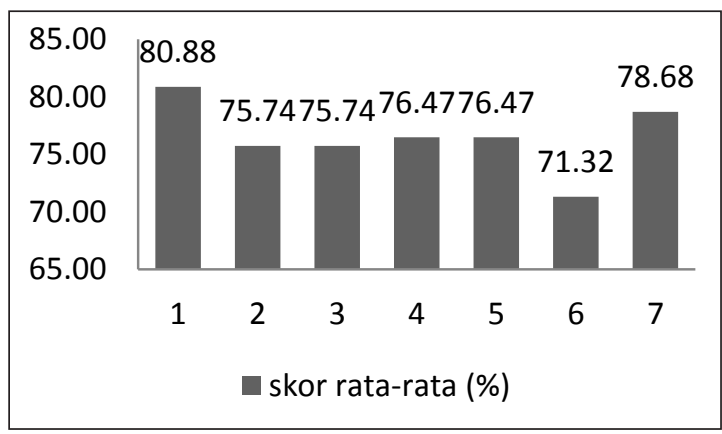

Gambar 3. Persentase Skor Rata-Rata

Keterangan

1. Mendengarkan penjelasan dari guru

2. Memakai seragam sesuai tata tertib

3. Mengerjakan tugas yang diberikan oleh guru

4. Membuat kegaduhan/keributan di dalam kelas

5. Mengganggu teman saat belajar

6. Melakukan kegiatan lain pada saat guru menjelaskan

7. Terlambat memasuki ruang belajar

Berdasarkan gambar di atas, persentase siswa yang mendengarkan penjelasan dari guru sebesar $80,88 \%$, siswa yang menggunakan seragam bengkel pada saat pelajaran praktik sebesar $75,74 \%$, siswa yang telah mengerjakan tugas yang diberikan oleh guru sebesar $75,74 \%$. Siswa yang melakkukan tindakan negatif saat proses pembelajaran berlangsung seperti membuat kegaduhan/keributan di dalam kelas sebesar $76,47 \%$, menganggu teman saat belajar sebesar 76,47\%, melakukan kegiatan lain pada saat guru menjelaskan sebesar $71,32 \%$, dan siswa yang terlambat memasuki laboratorium sebesar 78,68\%. jumlah siswa yang melakukan kegiatan negative masih cukup tinggi.

Berdasarkan hasil analisis statistik deskriptif terhadap skor rata-rata yang diperoleh siswa, dapat dideskripsikan nilai sikap berdasarkan penilaian antar teman pada siklus kedua dengan mengkategori frekuensi siswa sebagai berikut:

Tabel 4. Frekuensi Nilai Afektif Siklus Kedua

\begin{tabular}{ccc}
\hline Kategori & Frekuensi & Persentase \\
\hline Sangat Baik & 4 & $11,76 \%$ \\
Baik & 24 & $70,59 \%$ \\
Cukup & 6 & $17,65 \%$ \\
Kurang & 0 & $0,00 \%$ \\
\hline
\end{tabular}

Berdasarkan Tabel di atas, menunjukkan adanya peningkatan jumlah siswa yang masuk kedalam kategori sangat baik sebanyak 4 siswa sekitar $11,76 \%$, baik sebanyak 22 siswa sekitar $70,59 \%$, dan cukup sebanyak 8 siswa sekitar $17,65 \%$. Jadi siswa yang lulus pada nilai sikap sebesar $82,35 \%$ Penilaian sikap menunjukkan masih tingginya persentase kegiatan negatif yang dilakukan saat pembelajaran berlangsung. Hal tersebut terjadi dikarenakan keaktifan yang mulai meningkat sehingga ada beberapa siswa memanfaatkan situasi tersebut.

Hasil motivasi belajar siswa pada siklus kedua dikategorikan, sebagai berikut:

Tabel 5. Frekuensi Motivasi Belajar Siklus Kedua

\begin{tabular}{ccc}
\hline Kategori & Frekuensi & Persentase \\
\hline Sangat baik & 0 & $0 \%$ \\
Baik & 31 & $91,18 \%$ \\
Cukup & 3 & $8,82 \%$ \\
Kurang & 0 & $0 \%$ \\
\hline
\end{tabular}

Berdasarkan tabel di atas, menunjukkan 31 orang masuk kategori Baik dengan persentase $91,18 \%$ dan jumlah siswa yang masuk kategori Cukup sebanyak 3 orang dengan persentase $8,82 \%$.Terdapat penurunan jumlah siswa yang masuk dalam kategori Cukup. Penurunan disebabkan oleh jumlah siswa yang kurang memperhatikan materi pelajaran mulai berkurang, sehingga rasa percaya diri siswa meningkat. Selain dari pada itu, siswa yang pasif ketika mengikuti pembelajaran jumlahnya sudah mulai berkurang. Penurunan tingkat kepasifan terlihat ketika guru memberikan kesempatan untuk bertanya materi yang belum difahami dan mencoba menjawab pertanyaan yang diberikan guru meski salah.

\section{Siklus Ketiga}

Ketercapaian ketuntasan siswa mencapai 30 orang dengan persentase sebesar $88,24 \%$ dan 4 orang belum tuntas dengan persentase sebesar $11,76 \%$. Standar deviasi (SD) sebesar 0,29 penyimpangan data nilai yang diperoleh siswa memiliki variabilitas rendah. 


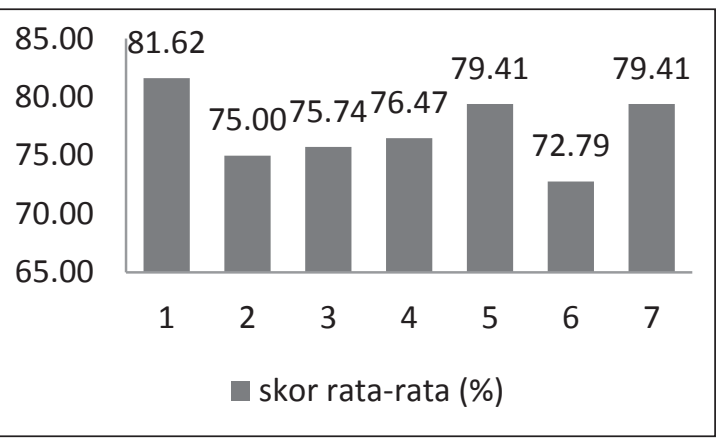

Gambar 4. Persentase Skor Rata-Rata

\section{Keterangan}

1. Mendengarkan penjelasan dari guru

2. Memakai seragam sesuai tata tertib

3. Mengerjakan tugas yang diberikan oleh guru

4. Membuat kegaduhan/keributan di dalam kelas

5. Mengganggu teman saat belajar

6. Melakukan kegiatan lain pada saat guru menjelaskan

7. Terlambat memasuki ruang belajar

Berdasarkan Gambar di atas, menunjukkan persentase siswa yang mendengarkan penjelasan dari guru sebesar $81,62 \%$, siswa yang menggunakan seragam bengkel pada saat pelajaran praktik sebesar $75,00 \%$, siswa yang telah mengerjakan tugas yang diberikan oleh guru sebesar $75,74 \%$. Siswa yang melakukan tindakan negatif pada saat proses pembelajaran berlangsung, yaitu: membuat kegaduhan/ keributan di dalam kelas sebesar $76,47 \%$, menganggu teman saat belajar sebesar $79,41 \%$, melakukan kegiatan lain pada saat guru menjelaskan sebesar $72,79 \%$, dan siswa yang terlambat memasuki laboratorium sebesar 79,41\%.

Berdasarkan hasil analisis statistik deskriptif terhadap skor rata-rata yang diperoleh siswa, dapat dideskripsikan nilai sikap berdasarkan penilaian antar teman pada siklus ketiga dengan mengkategori frekuensi siswa sebagai berikut:

Tabel 6. Frekuensi Nilai Afektif Siklus Ketiga

\begin{tabular}{ccc}
\hline Kategori & Frekuensi & Persentase \\
\hline Sangat Baik & 6 & $17,65 \%$ \\
Baik & 25 & $73,53 \%$ \\
Cukup & 3 & $8,82 \%$ \\
Kurang & 0 & $0,00 \%$ \\
\hline
\end{tabular}

Berdasarkan hasil analisis data nilai sikap, terdapat peningkatan kearah yang lebih baik dengan peningkatan jumlah siswa yang tuntas. Jumlah siswa yang lulus pada kategori Sangat baik sebanyak 6 siswa dengan persentase sebesar 17,65\% dan kategori Baik sebanyak 25 siswa persentase sebesar $73,53 \%$. Jumlah siswa yang belum tuntas pada kategori Cukup sebanyak 3 siswa dengan persentase sebesar $8,82 \%$, jadi persentase kelulusan nilai sikap sebesar $91,18 \%$

Hasil motivasi belajar siswa pada siklus ketiga seluruhnya masuk pada kategori Baik, sebagai berikut:

Tabel 7. Frekuensi Motivasi Belajar Siklus Ketiga

\begin{tabular}{ccc}
\hline Kategori & Frekuensi & Persentase \\
\hline Sangat baik & 0 & $0 \%$ \\
Baik & 34 & $100 \%$ \\
Cukup & 0 & $0 \%$ \\
Kurang & 0 & $0 \%$ \\
\hline
\end{tabular}

\section{Pembahasan}

Hasil analisis deskriptif menunjukkan bahwa peningkatan hasil belajar baik dari hasil tes teori, praktik, dan sikap. Ketuntasan hasil belajar pada nilai kognitif dan psikomotor terjadi peningkatan dari siklus pertaman, kedua, dan ketiga. Lebih jelasnya dapat dilihat pada Gambar 5.

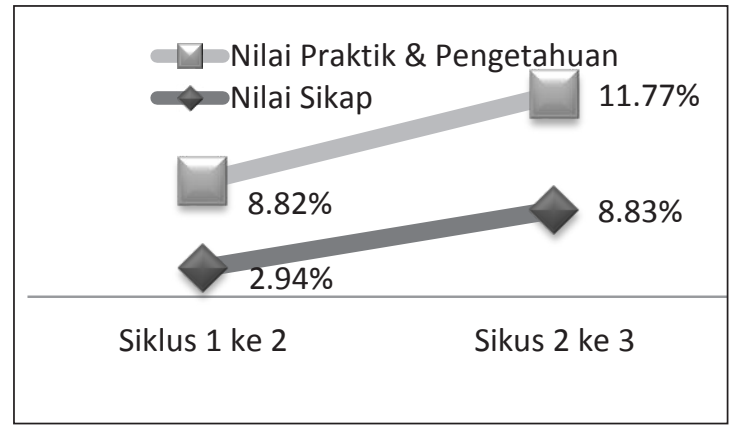

Gambar 5. Ketuntasan Kognitif dan Psikomotor

Pada siklus 1 dari 34 siswa yang tuntas sebanyak 23 siswa dengan persentase sebesar $67,65 \%$, siklus 2 sebanyak 26 siswa dengan persentase sebesar $76,47 \%$, dan siklus 3 sebanyak 30 siswa dengan persentase sebesar 
$88,24 \%$. Jadi peningkatan antar siklus yaitu: dari siklus 1 ke siklus 2 terjadi peningkatan sebesar $8,82 \%$ dan dari siklus 2 ke siklus 3 sebesar $11,77 \%$.

Nilai afektif terjadi peningkatan tiap siklus ke dalam kategori Baik, sehingga terjadi penurunan pada kategori yang lain. Lebih jelas dapat dilihat pada Gambar 6.

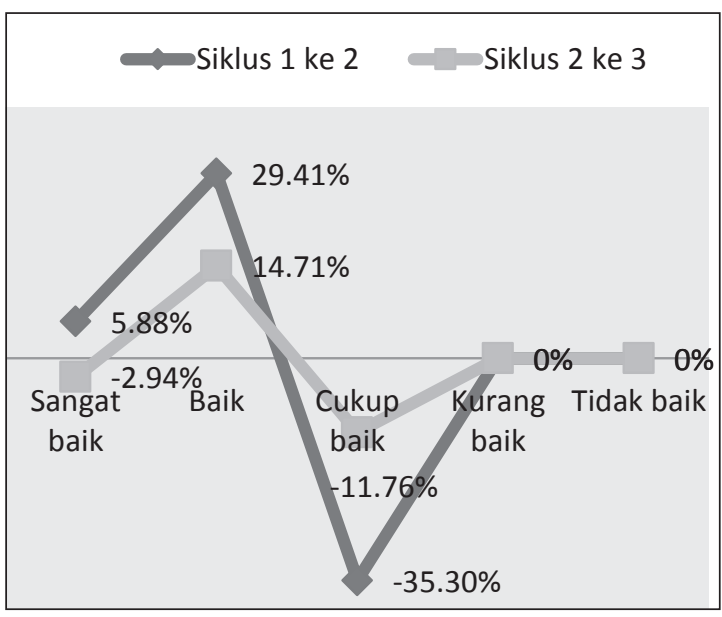

Gambar 6. Peningkatan Motivasi Belajar

Pada siklus 1 dari 34 siswa yang masuk dalam kategori baik dan dinyatakan tuntas sebanyak 27 siswa dengan persentase sebesar $79,41 \%$, siklus 2 sebanyak 28 siswa dengan persentase sebesar $82,35 \%$, dan siklus 3 sebanyak 31 siswa dengan persentase sebesar $91,18 \%$. Jadi peningkatan antar siklus yaitu: dari siklus 1 ke siklus 2 terjadi peningkatan sebesar $2,94 \%$ dan dari siklus 2 ke siklus 3 sebesar $8,83 \%$.

Motivasi belajar siswa terjadi peningkatan keaarah kategori Baik dari tiap-tiap siklus. Lebih jelas dapat dilihat pada gambar 7.

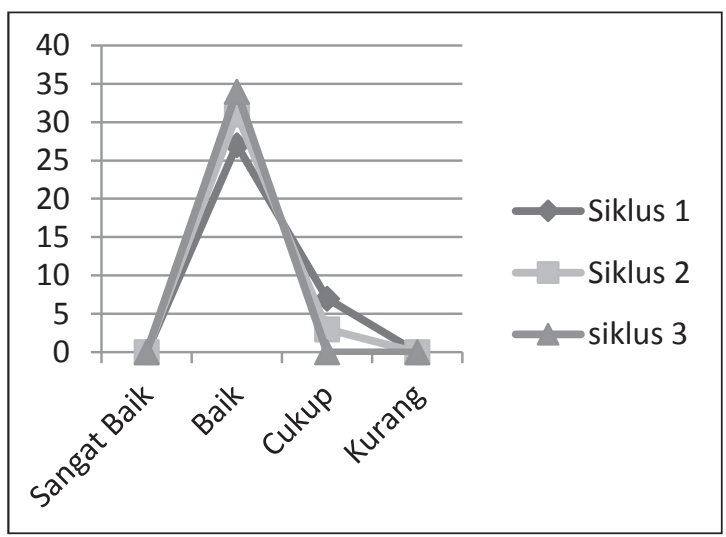

Gambar 7. Peningkatan Motivasi Belajar
Peningkatan motivasi belajar dari siklus 1 ke siklus 2 pada kategori Baik sebesar $11,76 \%$, sedangkan pada kategori Cukup terjadi penurunan sebesar $-11,76 \%$. Siklus 2 ke siklus 3 terjadi peningkatan pada kategori Baik sebesar $8,82 \%$, sedangkan pada kategori Cukup sebesar $-8,82 \%$.

\section{SIMPULAN DAN SARAN}

\section{Simpulan}

Penerapan media pembelajaran berupa modul dapat meningkatkan motivasi belajar siswa pada mata pelajaran pemograman dasar, yang dilaksanakan pada peserta didik kelas $\mathrm{X}$ semester 2 jurusan Multimedia tahun pelajaran 2014/2015 di SMK Negeri 2 Sumbawa. Penerapan media pembelajaran berupa modul dilakukan dalam 3 siklus, setiap siklus mengalami peningkatan kearah yang lebih baik. Siklus pertama, jumlah siswa yang masuk ke dalam kategori Baik sebanyak 27 orang dengan persentase sebesar 79,41\% dan kategori Cukup sebanyak 7 orang dengan persentase sebesar $20,59 \%$. Siklus kedua, jumlah siswa yang masuk kategori Baik sebanyak 31 orang dengan persentase sebesar $91,18 \%$ dan kategori baik sebesar 3 orang dengan persentase sebesar $8,82 \%$. Siklus ketiga seluruh siswa masuk ke dalam kategori Baik sebesar 100\%.

Penerapan media pembelajaran berupa modul pembelajaran dapat meningkatkan hasil belajar. Hasil belajar terbagi dalam 2 yaitu nilai sikap dengan ketuntasan minimal pada kategori Baik, sedangkan nilai pengetahuan dan praktik sama sebesar 2,66 (B-). Hasil belajar pada nilai sikap, yaitu: siklus 1 sebesar 79,41\%, siklus 2 sebesar $82,35 \%$, dan siklus 3 sebesar 91,18\%. Hasil belajar pada nilai pengetahuan dan praktikum, yaitu: siklus 1 sebanyak 23 orang dengan persentase sebesar $67,65 \%$, siklus sebanyak 25 orang dengan persentase sebesar $76,47 \%$, dan siklus 3 sebanyak 30 orang dengan persentase sebesar $88,24 \%$.

Berdasarkan hasil penelitian yang dilakukan sebanyak tiga siklus, penerapan media pembelajaran modul dapat meningkatkan motivasi belajar dan hasil belajar dapat mencapai ketuntasan klasikan $85 \%$ dari total siswa, yaitu: pada nilai pengetahuan dan 
praktikum sebesar $88,24 \%$, serta nilai sikap sebesar $91,18 \%$

\section{Saran}

Para siswa diharapkan untuk dapat menumbuhkan dan meningkatkan motivasi belajar yang berasal dari dalam diri dengan cara mengemas materi pelajaran ke dalam dunia yang disenangi, sehingga belajar menjadi hal yang menyenangkan.

Penelitian selanjutnya dapat menggali dan membuktikan lebih mendalam terkait penerapan modul untuk meningkatkan motivasi dan hasil belajar siswa.

\section{DAFTAR PUSTAKA}

Alias, N. \& Siraj, S. (2012). Design and development of physics module based on learning style and appropriate technology by employing isman instructional design model. The Turkish online journal of educational technology, 11, 84-93 diambil pada tanggl 26 gustus 2014, dari http://www.tojet.com

Alias, N., et al. (2014). Implementation of ptechls modules in rural Malaysia secondary school: a needs analysis. The Malaysia online journal of educational technology, 2, 30-35. diambil pada tanggal 26 Agustus 2014, dari http://v www.mojet.net

Buckingham, D. (2012). Media education: Literacy, learning, and contemporary culture. USE: Polity Press.

Carr, W. \& Kemmis, S. (1986) Becoming Critical. Education, knowledge and action research. Lewes: Falmer.

Hogan, R. L. \& Garling, N. (2008). Bortz's learning module: an alternative approach to training program curriculum development. Jurnal af Human Resource and Adult Learning, 4, 1-9. Diambil pada tanggal 26 Agustus 2014, dari http://www.hraljournal.com/Page/1\%20 R.\%20Lance\%20Hogan.pdf
Kustandi, C. \& Sutjipto, B. (2013). Media pembelajaran: manual dan digital edisi kedua. Bogor: Ghalia Indomesia.

Lopez, C. M. (2012). Vocational higt school or vocational college? Comparing the transition from school to work (page:2:32). Bonn:IZA.

Munadi, S. (2012). Penerapan asesmen kinerja dalam praktik proses pemesinan untuk pengembangan budaya kerja peserta didik (Pidato guru besar). Yogyakarta: Universitas Negeri Yogyakarta.

Pardjono, dkk. (2007). Panduan penelitian tindakan kelas. Yogyakarta: Lembaga penelitian Universitas Negeri Yogyakarta.

Reid, G. (2009). Motivasi siswa di kelas: gagasan dan strategi. (Terjemahan Hartati Widiastuti). London: Paul Chapmen Publishing. (Buku asli diterbitkan pada tahun 2007).

Robinson, J. W. \& Crittenden, W. B. (1972).

Sardiman, A.M. (2011). Interaksi dan motivasi belajar mengajar. Jakarta: PT. RajaGrafindo Persada.

Suprihartiningru, J. (2013). Strategi pembelajaran: teori \& aplikasi. Yogyakarta: Ar-Ruzz Media.

Trianto.(2010).Mendesainmodelpembelajaran inovatif-progresif: konsep, landasan, dan implementasinya pada kurikulum tingkat satuan pendidikan (KTSP). Jakarta: Kencana Prenada Media Group.

Yogaswara, W. (2011). Struktur kurikulum smk dan perhitungan jumlah jam produktif. Diambil pada tanggl 26 Agustus 2014, dari http://slideshare.netwanyora/ struk-kuri-smk-dan-perhitungan-jamproduktif.

Winkel, W.S. (2009). Psikologi pengajaran. Yogyakarta: Media Abadi. 